\title{
Research on teaching methods reform and insurance major graduates' employment adaptability
}

\author{
Fu Ronghui, Qin Lingling \\ Harbin Finance University, Harbin, China
}

Keywords: higher education; teaching methods; insurance major; improve employment adaptability

\begin{abstract}
The teaching methods of insurance major in the field of higher education should aim to improve students' comprehensive quality, employment ability, and should be reformed by adopting feasible measures. Insurance major graduates' employment adaptability has something to do with teaching methods. Graduates should strengthen their own quality and improve the employment adaptability.
\end{abstract}

\section{Introduction}

Most of the college graduates go to society and take jobs after university education is completed, so higher education quality is good or bad directly affects the university students' employment adaptability and their employment prospects, especially to insurance major students. So in colleges and universities' work: personnel training specification, curriculum offering, and teaching methods, etc, employment should be taken as the key. This is also the center of colleges and universities reform in recent years.

In 2012, the average college graduates scale is up to 6.8 million people. The number of graduates hits another high record. The employment task is arduous. In 1999, the relevant department published the employment rate of college graduates. In 2003, the ministry of education hooks school enrollment scale and graduate employment rate. The employment rate is one of the important indexes reflecting the running level of schools. The ministry of education counts every university, each major's employment rate and publicizes it to the society. One of the important reasons is to guide the major settings of colleges and make appropriate adjustments to fit the market by using the baton "employment". And in employment study course, the employment adaptability research is particularly necessary.

\section{Teaching method reform's mode exploration}

Traditional teaching method is lecturing. Cramming education is used until today and is still the overwhelming teaching method that our teachers commonly used. This method severely fetters the students' initiative so that the students can only passively accept knowledge and can't exert the students' autonomous learning enthusiasm. In response to this, the reform of the teaching methods can consider the following several aspects:

Case teaching. Through the cases, students deepen the understanding of knowledge. Here the teacher's ability of talking cases should be paid attention to. The cases shall be taught as vivid and interesting story and avoid dry and careless. This not only cannot help students understand knowledge, but make students lose interest in learning. Insurance courses' case selection includes:

1) Classic cases

Every course can be taught with classical cases, even if mathematics course, Gaussian, Chen Jingrun, Hua Luogeng's stories can also be taught. In political education courses, celebrity inspiring stories, sacrificed martyrs, touched Chinese characters, etc. should be talked about; in law course, all kinds of influential typical dispute cases should be talked about; in marketing class, Japanese sales god- Yuan Yiping's story can be told. In teaching insurance contracts' interpretation principles, there is one "give explanations in favor of the insured and the beneficiary". This rule is derived from a classic case of the early 16th century: sea risk underwriter Martin expands the business to human risk 
in the Gregorian calendar in June 18 in 1536, accepted insurance for a man named Gibbon with timeline of 12 months. Gibbon died on May 29 in 1537. His family claimed compensation to Martin. Martin said the timeline of 12 months is according to the lunar calendar which means a month contains 28 days, so the policy has been expired in May 20 in 1537, thus rejected the claim. The court decision was that the insurance timelimit two parties disputed should be calculated in accordance with common sense of the Gregorian calendar, and sentenced Martin to compensate. This case now evolves to one interpretation principle of insurance contract " give explanations in favor of the insured and the beneficiary".

2) The case of keeping pace with the times

This mainly refers to the cases capture times, such as in insurance compensation, there is a kind of compensation called accommodation settlement. It means that insurance company has no responsibility or liability for the loss compensation. For some reasons, insurance company gives all or part of the compensation. Accommodation settlement has certain principles, not casually compensate: (1) the volume is very big and credit is fine; (2) benefit for the business development of insurance company; (3) benefit for market competition and customers maintenance,and the reputation maintenance; (4) can form a good social effect. "SARS" in 2003 was a typical violent contagion. Because it was a new disease, it had not been mentioned in the insurance company's insurance liability. So general interpretation won't compensate, but in fact, all insurance companies made the decision of the insurance compensation for the available medical insurance. This belongs to the typical accommodation compensation cases.

Discussion teaching. This method plays a very important role in deepening students' understanding and mastering knowledge. Generally speaking, discussion can be used to solve the problem students confused. Especially some teaching contents related to the current affairs and let the students discuss which will receive better teaching effect. For instance, "Insurance Law" made the second revision in 2009. Let the students discuss why the "Insurance Law" should be revised. Discuss from "insurance law" promulgated for implementation in 1995 to now, the insurance industry faces changes in the environment, etc.

Current politics teaching method. Current politics teaching is to combine practice in the process of teaching. Introduce some current social political and economic situation into teaching process to make knowledge have the times sense. On May 12, 2008, Sichuan Wenchuan happened eight-level earthquake, causing serious personal casualty and property loss. Disaster recovery work lasted three years and cost $\$ 1.7$ trillion. This is the most realistic case in the course of the insurance risk. Teachers should extend to students the earthquake risk related content, introduce the basic situation of earthquake risk in our country and earthquake risk treatment of insurance field.

PBL teaching type. PBL teaching method (Problem-Based Learning), which is based on Problem Based Learning method, takes controversial problems in reality as the starting point, divides the students into various groups, let the student to carry on the analysis, discussion, judgment and evaluation, and get solutions by utilizing the existing knowledge. Finally Learn implicit science knowledge behind problems in the process of solving problems. Form the ability to solve problems and promote autonomous Learning and lifelong Learning ability. This method is used in training insurance talents, and it is very important to train the students the analysis ability of insurance problems and more conducive to the realization of "practical" insurance personnel training objective.

\section{Insurance major graduates' employment adaptability investigation and analysis}

Through the survey of insurance major graduates in Harbin Financial Institute during 2010-2012 by handing out insurance issue investigation table and the information analysis is as follows:

\section{Adaptive investigation and analysis}

Questionnaire table containing work time, work change, professional relevance, knowledge application degree, working conditions, rising channel, teaching method to the work influence surveys the respondents. By survey and analysis, the basic situation is as follows:

Tab 1. The survey and analysis, the basic situation 


\begin{tabular}{|l|l|l|l|l|}
\hline $\begin{array}{l}\text { Research } \\
\text { project }\end{array}$ & \multicolumn{4}{|l|}{ Research content and proportion } \\
\hline Working time & 1 year 75\% & 2 year 25\% & 3 year 0\% & 3 years or above 0\% \\
\hline Replace the work & didn't change67\% & change one 17\% & change two 8\% & change many 8\% \\
\hline $\begin{array}{l}\text { Professional } \\
\text { correlation }\end{array}$ & related 42\% & not related 58\% & & \\
\hline $\begin{array}{l}\text { Knowledge } \\
\text { application } \\
\text { degree }\end{array}$ & $30 \%$ below 50\% & $30 \%-50 \% 42 \%$ & $50 \%$ above 8\% & \\
\hline $\begin{array}{l}\text { Case teaching } \\
\text { method general }\end{array}$ & Very effective 42\% & Effective 50\% & Less effective8\% & \\
\hline $\begin{array}{l}\text { unit } \\
\text { impression }\end{array}$ & better future 58\% & make a living 42\% & & \\
\hline Rising channel & Relatively smooth 67\% & Not smooth 33\% & & \\
\hline $\begin{array}{l}\text { Working } \\
\text { conditions }\end{array}$ & Very satisfied 33\% & Normal 67\% & Not satisfied 0\% & Very unsatisfied 0\% \\
\hline $\begin{array}{l}\text { PBL teaching } \\
\text { method use }\end{array}$ & Better effect 100\% & General effect 0\% & No effect 0\% & \\
\hline
\end{tabular}

The survey subjects includes Heilongjiang Long Xiang insurance brokers limited company, Taikang Life Insurance Heilongjiang Branch Electric Selling Department, Xinhua Insurance Qiqihar Central Sub-branch Rich Marketing Service, China Ping An Life Tianjin Branch, Qiqihaer city Rural Credit Cooperatives and other several units.

\section{The adaptability relationship between teaching method and employment}

1) Case teaching method is limited to fixed knowledge

Usually many contents of insurance clauses come from the classical cases. While teachers are giving interpretation, the case can be introduced to enhance students' learning interest. While its defects are also very obvious, this case is usually only for a certain knowledge and lack corresponding expanding, which makes students difficult to form knowledge system. But in comparison, it is still better than teachers' bald teaching. From the above research, we can see that there are ninety percent students approve case teaching method.

2) Discussion teaching method is often a mere form

Adopting discussion teaching method often can't get the predetermined effect considering student's vision, horizon, and professional accomplishment. Because students may not know the panorama of a lot of significant events. It is difficult to grasp the national macro economic development. Many laws and regulations change is closely related with social development and progress and the national macro economic development changes. As the student whose main life is on campus, the lack of understanding is inevitable.

3) PBL teaching method analysis

The core value of PBL teaching method is "problem" consciousness. With the "problem" as the starting point, promote the students to conduct in-depth analysis and research of the proposed a "problem". In this teaching method, the representative and quality of case and project determine the quality of classroom teaching. We advocate the application of case and problems in course should come from industry practice. Application effect not only depends on the high quality "problem" and high quality teachers, but also depends on whether the students have good "problem" consciousness. Compared with other methods, PBL teaching method pays more attention to the systematicness and comprehensiveness of the knowledge, and can encourage students' enthusiasm and initiative. But the teaching method asks high requirements for teachers' profession and the cultivation of students' autonomous learning ability. In the teaching process, both teachers and students often appear the phenomenon of carelessness, so it is difficult to achieve the desired effect.

\section{Countermeasures for improving employment adaptability through teaching reform}


Teaching reform should be benificial to enhance graduates' employment confidence. In the beginning of employment, insurance graduates generally do insurance salemen, and cannot be directly engaged in the insurance management or the office work. Insurance is an industry frequently encountering setbacks. Insurance marketing methods are presenting the acquaintance method (do insurance with acquaintances) and stranger visiting method (do insurance with strangers). The acquaintance method can do limited people, and stranger visiting method is the main way to presenting insurance. In the process, salesmen's employment confidence is a big test. First win the strangers' trust, and at the same time get to know if he (she) has the strength of buying insurance. Insurance companies now generally require daily stranger visiting quantity of ten people, some twenty. In the 10 to 20 people, at most 2 to 3 people approve the insurance, in other words, more than $80 \%$ of your visiters are not interested. This is a big test to salesmen's confidence. Therefore, successful insurance marketing people all have strong personality.

In the teaching reform, the special curriculum design can be done with role playing. In the use of PBL teaching method, teachers may put forward a specific range of clients. Students need to understand common psychology and usual impression of this kind of customers, and choose the right marketing means. so, the trainings in class can greatly shorten the students' fear feeling in doing their work in the future, and setting up work confidence.

Teaching reform and curriculum should include the content of customer psychology study. The sale of insurance is a kind of invisible risk guarantee. Not to mention the traditional Chinese fond psychology, from the characteristics of insurance goods, because it is invisible, the customers are very difficult to understand from the surface. So insurance marketing should be based on customer psychology, make them agree with insurance and finally produce the desire to buy. This requires marketing salesmen to master the customer psychology. Because in real life, there are many people who have the ability to buy insurance didn't buy insurance. This shows that there has not been a man really touched his heart.

This teaching reform and curriculum should include in the content of customer psychology study. The curriculum problems are complicated and have long cycles, and at the same time, the curriculum is the key of the whole course, so the teaching reform should be paid effort to. The main idea of teaching reform is to serve for students employment, and insurance students may frequently contact with all kinds of clients. Therefore, teachers should dabble in some customers' psychological contents and teach students in each insurance course. The concrete ways are lectures type, case auxiliary type, group discussion, material-collecting type, etc.

Study to improve the customer satisfaction RATER index in teaching reform. Real customer service satisfaction refers to customers' service expectations based on their personal needs, his past service experience, and the enterprise service reputation.

The most authoritative customer service research institutions in the United States BBS company employed hundreds of research personnel and did a thorough investigation and study on nearly customer service personnel and the industry customers of 14 industries of retail, credit card, bank, manufacturing, insurance and service maintenance in nearly 10 years and found a RATER index which can effectively measure customer service quality. RATER index is the abbreviation of five English words: reliability (reliability), assurance (professional degrees), tangibles (tangible degrees), empathy (similarly degrees), responsiveness (reaction degree). And customer satisfaction for enterprise directly depends on RATER index.

The insurance industry has a jargon: "Do insurance, first be a man". This is particularly important to the greenhands. Because the fledglings first consider how to complete their performance. In the acquisition process, often reflect indifferent feelings to the nonstandard customers, and it is quite harmful. Because from the angle of interpersonal relationship, he (she) may not buy insurance because disagree with it or without economic ability, but this does not mean that the people around he (she) do not agree with the insurance or can't afford to buy insurance. But if we are cold to him (her), the people around he (she) have low possibility of buying insurance from you.

In designing by using teaching methods, refining should be based on RATER index. While using PBL teaching method, the design should be close to the actual real problem of the insurance industry. 
The students should conduct group discussion, have a clear division of work, and cooperate with each other, have mutual understanding, and mutual promoting; on the one hand, cultivate the students' team cooperation spirit, on the other hand let the students more agilely use insurance professional knowledge, and help students strengthen the knowledge of insurance industry development method. It has great inspiration in university study plan and job planning.

To get better grades in the work, insurance graduates must have profound professional skills and great individual efforts. Textbook knowledge is just the carrier, and teaching method are just tools. Agilely use knowledge is a person's literacy and ability, so the core of successful work is to make great efforts to improve personal accomplishment.

\section{Conclusion}

With the rapid development of Internet technology, network structure is becoming more and more complicated; network security has become increasingly important and complicated. This paper puts forward an intrusion detection system under IPv6 platform based on intrusion detection feature attribute reduction by using pattern matching, so as to expand the range of application and user group of the security products. By the analysis and comparison of various pattern matching algorithms, the new algorithm realizes the intrusion feature module matching under IPv6, and make detection system be of high efficiency. Later experiments have proved this view.

\section{Acknowledgment}

The paper belongs to the mid-term research results of " Countermeasure study of PBL teaching method in the cultivation of insurance talents " in Heilongjiang province vocational education society

" The twelfth five-year plan" planning subjects, Subject Number: GG0368

\section{References}

[1] Zhang LiHua, Yang MingFang. In 2012, the number of college graduates peaked again [N]. The People's Daily, 2012.4.14

[2] Wang Shikai. Insurance contract benificial interpretation principle research [D]. Jilin University, 2007

[3] Li Ming, Zhang Jie, Zhao ShiXiu. PBL teaching method's countermeasures study in insurance teaching [J], Financial Theory and Teaching, 2012 (3), -

[4] Pin Yichen. Customer satisfaction [DB/OL]. Baidu encyclopedia, 2012.6.29 